\title{
The historical Jesus and the search for God
}

\author{
Stephen J Patterson
}

Eden Theological Seminary St Louis, Missouri, U S A

\begin{abstract}
Since the advent of the first quest for the historical Jesus in the nineteenth century, theologians have felt compelled to accept as normative either the Jesus of history (so Liberal Theology) or the Christ of faith (so Kerygmatic Theology). This choice is a false one, for the structure of early Christian faith involves both historical and confessional elements in the creation of meaningful theological discourse. We can recover the poetics of that discourse if we clearly distinguish between the historical and confessional elements in the gospels, and place them once again in a dialectical relationship. In this way, the quest for the historical Jesus may retain its character as an historical discipline, and yet still prove fruitful for critical theological reflection.
\end{abstract}

Anyone who has followed the debate about the historical Jesus during the last decade must have been astonished or even horrified to observe how, as in a volcanic area, the earth was suddenly everywhere spewing forth fire, smoke, and differently-sized masses of lava, where, for a generation past, pleasant gardens had been planted on the slopes of ancient craters. Exegetes and systematic theologians, Protestants and Catholics, one's own school and its opponents (not least what was once the New World), our students and even the so-called lay people have been drawn into the uproar and have made strenuous efforts to extend the fireworks display.

(Ernst Käsemann [1965] 1969:23)

\section{INTRODUCTION}

Who was Jesus, historically speaking? Every generation or so scholars of the New Testament find themselves returning again to this very old, yet very important question. For Christians - and to some extent, anyone involved in the course and flow of Westem history - it is a question about origins, about roots, about beginnings. It is an orienting question that takes us back to basics. How did Christianity begin? Who was 
this person in whom generation upon generation of Christians have claimed to see God, in whose name Christians have risen to the heights of what it means to be human in acts of care and compassion, and sunk to the very depths of demonic possession in acts of brutal oppression and violence? These questions draw us back time and agin because they are foundational to our understanding of who we are as a culture, and what we would like to be. The quest for the historical Jesus involves more than mere historical inquiry into the life of a famous and influential person. It is a loaded question. It has become a question about ourselves and our search for God.

\section{THE QUEST FOR THE HISTORICAL JESUS AND THE SEARCH FOR GOD}

The question of the historical Jesus did not first arise in our time. Problems with the historicity of the gospel texts have plagued scholars since the eighteenth century, when the full force of the Enlightenment began to make itself felt, especially in areas of religious faith. The origins of the problem are not mysterious. The idea that everything we read in scripture is literally, historically true could simply not be maintained in the face of new information about the way the world works that was turned up by the new disciplines of history, geography and science. The question of the historical Jesus arose when scholars first began to notice that the gospel texts come with an entire world view, an ancient world view that grants the plausibility of things a modern world view simply will not. ${ }^{1}$ For example, for ancients, who thought about heaven as a vaulted space above the sky, it made sense to speak of Jesus' final 'ascent' into heaven. For modern persons, whose world view includes space and planets, atmosphere and ozone, this no longer makes sense. But if this part of scripture cannot be literally true, then what is true? And in what way can something be considered true? And how shall that be determined, and by whom? The intellectual challenge of the Enlightenment was really about the ability and authority to name what is true and what is not. Insofar as the Bible is finally about ultimate reality, ultimate truth, the question of the historicity of the Bible, and with it the question of the historical Jesus, has always been bound up closely with the search for Truth. Thus, the quest for the historical Jesus has, from its very beginning, also been about the search for God.

\subsection{The Enlightenment and religious faith}

To many people today the Enlightenment, with its emphasis on reason and natural law as the basis for understanding all that there is to know about the world, now seems like a vain attempt to subjugate everything to human control and validation, to impose 
arbitrary structure on what is ultimately chaos. However, whatever its shortcomings and moments of hubris might have been, one should not forget what the Age of Reason meant as an advance over what had preceded it, especially in the realm of religious faith. The Enlightenment was about the democratization of authority to name what is true and what is not. Prior to the Enlightenment, the power to say what is true lay with vested authority. In the church it lay with priests and bishops, and ultimately the Pope. The Protestant reformers had begun to challenge this authority already in the Reformation age using the tools of reasonable argumentation and criticism. In his dispute with Cajetan, for example, Martin Luther could argue that 'any one of the faithful' has authority above that of the Pope 'if armed with a better authority and reason'.2

In the Enlightenment this principle reigned free. The power to name what is true fell to anyone who could make a reasoned defense of an idea. This was true, of course, especially in the study of the natural world, which was discovered more and more to behave according to consistent 'laws of nature.' But science in the seventeenth and eighteenth centuries was not a discipline altogether separate from religion. Renaissance heroes like Galileo and Spinoza were not only scientists, they were philosophers and theologians as well. After all, the Bible had its own theories about how the universe was created and sustained. When new scientific ideas grounded in reason and criticism came into conflict with the Bible, scientists found themselves standing before the Inquisition defending the theological implications of their views. Galileo paid for the advances we all owe to him with the final years of his life, spent under house arrest and in forced seclusion in Florence. Spinoza was excommunicated from the synagogue, and for a century after his death was persona non grata in the cultured circles of Europe.

By the eighteenth century the Enlightenment was in full swing. Challenge to ecclesiastical authority was no longer a life-threatening adventure, but it could still land one in plenty of hot water. The battle and the booty were still the same: who has the authority to name what is true? The church claimed this authority for itself. Scientists, philosophers, and breakaway theologians claimed it for anyone with a reasonable argument. Their attinde toward the church was frequently hostile and distrustful. They saw its defense of supernaturalism and the literal truth of the scriptures as an attempt to shore up its authority in the face of spreading populism and egalité.

\subsection{Reimarus and the beginning of the Quest}

In this atmosphere the forebear of modern critical scholarship on the gospels labored in secret. Hermann Samuel Reimarus was a German Deist, theologically trained, but posted in the philosophical faculty at Wittenberg, and later as a professor of oriental 
languages in Hamburg. His was not a stellar academic career. In fact, no one would have known of this obscure figure had his private notes on Jesus and Christian origins not been published posthumously and anonymously by $G \mathrm{E}$ Lessing in installments between the years 1774 and 1778. But in the fragmentary notes of this obscure professor, there lurked a revolution. The crucial final installment, entitled On the intentions of Jesus and his disciples, provoked the Duke of Brunswick to demand that Lessing immediately turn over his mysterious manuscript and cease all further publication. ${ }^{3}$

Reimarus assessed the Enlightenment struggle between reason and church authority and read it into the problem of gospel origins. Reading the gospels with enlightened eyes, he saw in them the simple story of a martyred teacher that had been augmented and aggrandized by adding tales of the miraculous, supernatural intervention, and in the end, a resurrection. He attributed these accretions to the apostles, who, according to Reimarus, created such legends around Jesus in order to transform Jesus' simple moral teaching into a supernatural religion. Turning the idea of apostolic succession on its head, he saw the apostles as the first bishops, establishing and defending their position of authority by asserting divine sanction for their views. In short, he argued that the church was, from the very beginning, a fraud. Small wonder that even after his death, Reimarus' family was reluctant to allow the publication of his notes, for fear that the reputation of his entire family would be ruined.

In retrospect one can now see that Reimarus' theory of gospel origins was grounded in his own struggle with the church. The story of gospel origins is in fact much more complicated than Reimarus imagined it. But his work did make a lasting impact. His relentless application of the standards of consistency and reasonableness left little in the gospels that could stand up as evidence in a court of law. No one could read Reimarus and come away unshaken in the notion that the gospels could somehow be construed as modern, reasonably constructed history. For anyone interested in the historical Jesus, everyone could now see that the gospels posed a serious problem.

\subsection{The Quest for the Historical Jesus}

Many who followed Reimarus held out the hope, however, that somehow buried in these incredible stories of miraculous feedings, walks on the sea, and corpses rising from the grave, one could find an historical kernel beneath the embellished husk. The Quest for the Historical Jesus was on. The late eighteenth and early nineteenth centuries saw the publication of literally hundreds of books and articles on the historical Jesus. But unlike Reimarus, many of these studies were done not in critical opposition to the church, but as a way of revitalizing the church by uncovering the pure moral religion of Jesus, freed from its ancient supernatural encasement. Like Reimarus, how- 
ever, they were all doggedly rationalistic in their approach. Among them one finds some of the most creative and fanciful explanations for Jesus' best known miracles. For example, it was once proposed that the Feeding of the Five Thousand was accomplished with the help of a secret band of co-conspirators, who planted themselves with a large quantity of bread in a cave that day on the hill side, which they passed out to Jesus as was needed. Or there is the theory that Jesus walked on water with the help of an extremely long raft extending out into the Sea of Galilee. ${ }^{4}$ This is also the origin of any number of theories explaining Jesus' resurrection (coma, physical shock, druginduced stupor - the list is as endless as the imagination) many of which are themselves periodically resurrected and repackaged as astonishingly new and bold ideas. They are not.

This was the first quest for the historical Jesus. The assumption of most of the early questers was that the gospels were at least intended to be read as historical reports. The only problem was that their authors were ancients, with naive and primitive assumptions about the world, unenlightened about the laws of nature and unfamiliar with rational thought. They were trying to write history, but were simply illequipped for the task. If one could simply see through their naive and primitive assumptions, one could find an historical core nestled beneath the layers of ancient naiveté. All of this work was chronicled by Albert Schweitzer at the end of the nineteenth century in his classic study, The Quest of the Historical Jesus. 5 It is often thought that Schweitzer brought the first quest to an end in this famous book, through his devastating review and dismantling of virtually every critical proposal from Reimarus to William Wrede. But this is not true. It is true that Schweitzer' was devastatingly critical of his predecessors, but he did not fundamentally challenge their approach. He, too, thought that the gospels could be read critically to glean from them an historical kernel. He simply disagreed with the results of those whose work preceded his. For his part, Schweitzer offered his own historical reconstruction of Jesus' life and ministry. We shall return to Schweitzer presently.

\subsection{Strauss' attack on history}

The end of the first quest for the historical Jesus came only when scholars began to realize that the gospels are not really historical sources at all. While the first questers were busy constructing reasonable lives of Jesus, the source of their undoing was already at work. He was David Friedrich Strauss. Strauss was not a product of the Enlightenment, but of its successor, Romanticism. The romantics did not repudiate the world view of the Enlightenment so much as they sought to supplement pure reason with a more humanistic approach to human culture and existence: human beings also 
'feel' things (Kant); they have a certain 'sensibility' (Rousseau); they have 'ideas' (Hegel). Strauss was impressed with the notion that truth might be borne in 'ideas,' and that ideas might find their representation in mythic stories and themes. In reading the gospels, Strauss became convinced that at base their story is not a history, but the mythic expression of an idea: that God is incarnate in humanity. The problem is that the gospels had become historicized in our thinking, so that the universal truth of God's incarnation in all of humanity had come to be seen as a unique event associated only with Jesus.

Strauss set out to prove his case through a thoroughgoing critical assessment of the gospels themselves in a massive, two-volume manuscript, first published in 1835 and 1836 when he was just 27 years old. ${ }^{6}$ His plan, though thorough, was quite simple. First, he joined the rationalist questers in dismantling the traditional supernaturalist position, by discounting the historicity of anything in the gospels that involved supernatural powers, direct intervention by God, or miraculous feats by Jesus. But then he turned around and attacked with equal vigor the rationalist position, by showing that once those transcendent elements of the story are eliminated, there is virtually nothing left. There is nothing in our gospels upon which to construct a reasonable, historical life of Jesus. If the gospels are not history, then what are they? Strauss argued that they are myth - myth, not in the sense of 'fairy tale' or 'faisehood,' but in the religious sense, as described by Hegel. Hegel spoke of myths as narratives that bear in themselves the content of eternal, universal 'ideas.' In Strauss' view, the gospels are mythic narratives that bear in themselves the universal idea of God's incarnation in humanity. To historicize them is to miss their point. The early church created them not to recount a history, but to give expression to what it had learned about God in Christ.

Strauss' position that the gospels are myth, not history, did not meet with warm regard. In attacking the supernaturalist position, he incurred the wrath of a still conservative state church. In attacking the rationalists, he alienated anyone who might have lent support to his position from a more liberal point of view. Though his book turned out to be very popular - owing to its controversial nature - its popularity could not save him. He lost his teaching position at Tübingen almost immediately and found himself blacklisted when others tried to find a position for him elsewhere. His own teacher denounced him as the 'Judas Iscariot of our time'. ${ }^{7}$ He spent much of his life bitter and depressed, and eventually withdrew from a career in theology out of sheer frustration.

But Strauss had planted the seed of an idea: that perhaps the gospels had not been written with the intention of recounting a history at all. It was this basic idea that 
turned out to be the undoing of the first quest, as well as the traditional Orthodox view that the gospels are literally, historically true. At the end of the nineteenth century this idea would be taken up again, but made more palatable by another German theologian, Martin Kähler, who was not a radical, but a conservative. What had been anathema to the church in the first half of the nineteenth century would at its end become the basis for a new orthodoxy.

\subsection{The Quest falters}

Throughout the nineteenth century, in spite of Strauss' insights, the quest for a rational, reasonable life of Jesus continued. But its results became increasingly meager, and the figure that emerged seemed less and less compelling as a complacent nineteenth century church struggled to find a Jesus with which it could be comfortable. In 1892 the quest for a Jesus who was both historically plausible and theologically relevant was dealt a critical blow. This was the year Johannes Weiss ([1892] 1971) published his study of the preaching of Jesus, in which he argued that Jesus was a preacher of apocalyptic doom, a prophet of the end time, who believed that the end of history was coming to pass in his own lifetime. This hypothesis, made more popular by Albert Schweitzer ([1906] 1910) after the turn of the century, has persisted unchallenged until our own day. 8 But its impact on the quest for the historical Jesus was devastating. It meant that when all was said and done, the quest had yielded a Jesus whose preaching, to the extent that it can be known at all, was motivated by notions about the end of the world to which we can no longer subscribe. As Schweitzer (1910:396-397) so deftly put it at the end of his masterpiece of reconstruction, this Jesus

will not be a Jesus to whom the religion of the present can ascribe, according to its long-cherished custom, its own thoughts and ideas, as it did with the Jesus of its own making. Nor will He be a figure which can be made by popular historical treatment so sympathetic and universally intelligible to the multitude. The historical Jesus will be to our time a stranger and an enigma.

To its credit, the first quest for the historical Jesus had sought to make Jesus relevant to a culture vastly different from the world of Jesus. But in Schweitzer's view, in their search for relevance, the questers had been forced to overlook something so crucial to the preaching of Jesus that without it, it would collapse into an unrecognizable heap: apocalypticism. Could a Jesus who saw himself as standing on the edge of apo- 
calypse, turning the wheel of history forward toward its final hour with the force of his own shoulder, could such a Jesus still mean something to our world?

Schweitzer (1910:397) himself was not troubled by this. He wrote, 'Jesus means something to our world because a mighty spiritual force streams forth from him and flows through our time also.' That spiritual force is to be found in the radically worldnegating sayings, the so-called 'hard' sayings of Jesus, which are quite in tune with apocalyptic's hostile stance over against the world. The problem with the nineteenth century lives of Jesus was that they offered a Jesus

who was too small, because we had forced Him into conformity with our human standards and human psychology. To see that, one need only read the Lives of Jesus written since the [eighteen]'sixties, and notice what they have made of the great imperious sayings of the Lord, how they have weakened down His imperative world-condemning demands upon individuals, that he might not come into conflict with our ethical ideals, and might tune His denial of the world to our acceptance of it. Many of the greatest sayings are found lying in a comer like explosive shells from which the charges have been removed. No small amount of elemental religious power needed to be drawn off from His sayings to prevent them from conflicting with our system of religious worldacceptance.

(Schweitzer 1910:398)

For his part, Schweitzer accepted his own challenge and allowed the radical sayings of Jesus to explode his own world. He gave up his academic post and found the Reign of God in deepest Africa, where he lived a life of radical world-negation. His convictions were legendary.

But what of those left behind amid the exploding shells, who could find comfort neither in the all too human, and now apparently failed attempt to secure faith through historical research, nor in the 'mighty spiritual force' streaming forth from Schweitzer's Jesus? Had the search for God come to a dead end in the quest for the historical Jesus?

\subsection{The end of the Quest}

In the midst of this despairing scene, Martin Kähler's ([1892] 1964) little book, The socalled historical Jesus and the historic Biblical Christ, written more than a decade ear- 
lier, now appeared like a knight in shining armor. Kähler was well-versed in the advances that had been made in the critical study of the Bible and had accepted its largely negative results. But he also grasped the problem that modern critical scholarship posed for Christian theology, which had always sought its authoritative grounding in scripture (for Kähler, a German Protestant, this was especially true). In his small, but enormously influential book, he posed the question in a way that is still relevant for many Christians today. As Carl Braaten (1964:10) phrased it in his introduction to the modern edition of Kähler:

How can the Bible be a trustworthy and normative document of revelation when historical criticism has shattered our confidence in its historical reliability? And how can Jesus Christ be the authentic basis and content of Christian faith when historical science can never attain to indisputably certain knowledge of the historical Jesus?

These were everyone's questions, not just Kähler's. But Kähler was not satisfied with the way in which they had been answered in his generation. In spite of warnings to the contrary, liberal theologians were still attempting to address them by treating the gospels as sources for a life of Jesus, using critical analysis to reconstruct a reasonable account of Jesus' life and career. Orthodox theologians were still attempting to address them by asserting ecclesiastical authority, insisting that the Bible is historical because the church says that it is. Faith in the Bible, in the form of biblical inerrancy, became a necessary prerequisite to faith in Jesus Christ. Both positions, however different, nonetheless shared a set of basic assumptions, and it was these assumptions that Kähler questioned: (a) that the gospels were intended to be read as history in the first place, and (b) that Christian faith should even be interested in an historical Jesus as its ground and starting point.

Kähler did not accept either of these propositions. The results of historical criticism for Kähler indicated that the gospels were never intended to be read as history in the first place - certainly not history in the way we have come to understand the concept since the Enlightenment. But never mind, said Kähler. The church is not really interested in the historical Jesus. It is not interested ultimately in where he went, what he did, or what he said. These things, while interesting, simply do not have any bearing on Jesus as he is seen to be significant to the church. The church is interested in that which makes Jesus significant for our lives. Its interest is not in the historical Jesus, what he really did and said, but in the historic Jesus. What makes Jesus signi- 
ficant to the church, to humanity? For Kähler it was his death and resurrection. This is the content of the gospel, for Kähler; it is aiso the content of the gospels. They are not histories intending to convey a teaching or an ethic, but 'passion narratives with extended introductions' (Kähler 1964:80 note 11).

So it matters not that the gospels are not historical. To insist that they are is to press upon them a requirement that they cannot, and need not, fulfill. But Kähler went further still. To insist, with Orthodoxy, on the historicity of the gospels is to insist that their claims be judged by a criterion established arbitrarily by our own particular human culture. History is our criterion, not the Bible's. He leveled the same criticism at the liberal quest for the historical Jesus. The search for an historical element within the text that could serve as the objective foundation for faith would be to put in danger the very nature of faith itself. Faith is always a risk to believe, to venture a life lived out of a transcendent reality. Kähler saw the quest for the historical Jesus as an attempt to minimize the riskiness of faith, to establish a kind of historical proof for one's claims. That would not be faith, but a flight from faith. The authority of the gospels, said Kähler, lay not in their historical accuracy, but in their ability to call forth faith in Jesus through generation after generation of Christians.

Kähler's approach to the problem proved compelling and persuasive for many generations of Christian theologians. In retrospect we can now see that it was really his work that brought to an end the first quest of the historical Jesus. As the search for God continued, it did so completely under his influence. The next generation of theologians. would be dominated by persons profoundly influenced by him, most notably Karl Barth and Rudolf Bultmann. These two giants of early twentieth century theology, often seen as opposite poles in the theological field of that time, were actually much more profoundly connected than they were separated - and the connection lies in Kähler. Both Barth and Bultmann assumed that the starting point for Christian faith is not the historical Jesus, but the saving action of his death and resurrection. This, for them, was the heart of Christian faith and preaching - it was the kerygma. Each worked out the implications of this early Christian kerygma in very different ways, Barth using the categories of traditional orthodoxy, Bultmann using existentialist philosophy. However, these two camps within Kerygmatic Theology shared one thing: the historical Jesus was not a necessary part of the equation. For the time being, the quest was off. 9

\subsection{The New Quest}

The quest has remained off for most European and American theologians for most of this century. European and American scholarship still stands under the influence of Barth and Bultmann, as the two schools of thought spawned by these compelling 
thinkers have branched into multiple forms and found a home in other lands.. One might easily say that the success of these theological paradigms and their ability to unfold ever new aspects of Christian faith and its significance for modern people has proven that Christian theology does not really need the historical Jesus. That is where the matter still stands for many theologians today. Christian theology begins with scripture, not history.

But a trip to the local bookstore will tell even the most casual observer of this drama that the problem of the historical Jesus has not really gone away. We are in the midst of a great resurgence in interest in the historical Jesus; seldom has scholarship so potentially arcane attracted such a broad popular audience. Where has this new interest come from?

It began more than forty years ago, when a former student of Rudolf Bultmann raised the question: Can Christian theology really manage without the historical Jesus? The student's name was Ernst Käsemann, and he raised his question at a meeting of Bultmann's former students known as the 'Old Marburgers,' in 1953.10 Käsemann answered his own question with a resounding 'no.' The sources themselves, argued Käsemann, will not allow us to renounce all interest in the historical Jesus. To be sure, the gospels as we have them are filled with Christian theology; they are not history. But they all cast that theology, give it expression, in terms of a life of Jesus. In other words, they all locate what they had come to see as decisive for our understanding of God within the very real life of a real person, Jesus. It matters not that their confessional way of recounting that life has all but obliterated any actual facts about Jesus. The one fact, that they cast their insights in the form of a life, says that the historical reality of this person is indispensable to the Christian understanding of who God is and how God works.

For Käsemann, the historical Jesus is theologically indispensable. In his historicity lies the particularity with which God encounters humanity. It is not in the abstract that one knows God, or through general principles, but in history, with all the particularity and challenge to decision that is found only in a human life. The gospels deciare that in this life, the life of Jesus, we have come to know God in a new way. The early Christian preaching about Jesus does not replace that life and render it superfluous; it confirms it and makes it decisive. It presents Jesus' life as kairos, a moment in history that demands a decision.

Käsemann also argued that historicity itself is important. It represents the claim that God chooses to reveal God-self in history, in the corporeality of human existence. In Jesus, God is near, not far. Käsemann thus called for a renewed effort to learn what we can about the historical Jesus, even though he knew that the methodological difficulties in evaluating the sources would be considerable. 
Käsemann's call led to a new phase in historical Jesus research, known as the New Quest. This term was coined by James M Robinson (1959), who also served as its chronicler and principle architect. The New Questers did not simply take up where the first Quest had left off. They did not return to a pre-Kähler understanding of the texts, treating them as naive history, whose facts need simply to be straightened out. They understood the theological nature of the texts. At the same time, however, they brought to their project a new understanding of history, which itself is not interested simply in the bruta facta. Drawing on the insights of R G Collingwood and Wilhelm Dilthey, they argued that a genuine interest in the past is motivated not by simple curiosity about what happened when, but by the desire to explore events in their significance for human beings, then and now. This new philosophy of history directed attention not to the bruta facta of history, but to the significance of the past for the present. But this is exactly the interest one finds expressed in the gospels. They, too, are not interested simply in preserving the facts about Jesus' life, but in presenting Jesus' life in all its significance for all who claim the name 'Christian.' So when the gospel writers selected materials and presented them in a way that emphasized the significance of Jesus, they did not thereby block all possibility for the modern historian to do his or her work. In a sense, their interest and that of the historian coincide: both are interested in that which makes Jesus significant for human existence (cf Robinson 1959:6672).

One might rightly sense in this program quite a different attitude toward the early church than that which characterized the first Quest. The first Quest, it will be recalled, was interested in Jesus before the church transformed him into an object of veneration, the Christ of faith. In the historical Jesus, they believed, one could find that originally pure moral religion that should claim our only true loyalty as Christians. The New Questers saw things differently. In their view, the early Christian proclamation did not replace Jesus' own preaching, but confirmed and continued it in a new form. The New Questers asked whether and to what extent the preaching of the early church was anticipated already in the preaching of Jesus himself. Käsemann, for example, believed that Jesus did not think himself to be the Messiah. Nonetheless, the first, second, and fourth antitheses of the Sermon on the Mount (Mt 5:26-30, 33-37), which Käsemann takes to be authentic words of Jesus, indicate that in his teaching Jesus elevated himself above the authority even of Moses. He thus concludes, "The only category which does justice to his claim (quite independently of whether he used it himself and required it of others) is that in which his disciples themselves placed him namely, that of Messiah' (Käsemann 1964:38). In this way the New Questers could stress the continuity between the preaching of Jesus and the preaching of the early 
church, even while making historical judgments about what could rightly be ascribed to each.

To make such distinctions the New Questers began what has become a long tradition of rigorous historical methodology to be applied to the gospel texts. First, they assumed that the texts were not primarily intended to be read as history. Thus, anyone wishing to make an argument for the historicity of this or that saying, parable, or story, had to face a stiff burden of proof. Anything reflecting the interests of the gospel writers or the situation of the early church of which they were a part, for example, could not be considered historical. Also, common traditions, popular lore that might readily be attached to any famous person in antiquity, also could not be considered ${ }^{11}$. On the positive side, unusual things, odd, clever, or difficult sayings, and the like, that could not readily be traced to popular culture or to the situation of the early church might more plausibly be attributed to Jesus himself. Or elements of the tradition that are attested independently in two or more independent sources might owe their origin to Jesus.

When conscientiously and rigorously pursued, such a methodology will of necessity be more complicated than can be dealt with here. The general picture of the procedure started by the New Questers, and in large measure continued today, is enough. 12 Above all, one can see that any attempt to find in the gospels anything like a complete portrait of Jesus will be somewhat of a disappointment. The portrait will not be a portrait at all, but a fragmentary picture - like a jigsaw puzzle with most of the pieces missing. Neither will this fragmentary picture be an 'objective' view of Jesus, any more than any historical procedure can claim objectivity. As participants in the human drama, all of us are much too involved in the human subject matter of history to claim objectivity. We can and must try to be fair, unprejudiced, and selfcritical in viewing the past, but pure objectivity lies beyond our grasp. This is the problem historical criticism has left us with. We cannot undo it, try as we might, even with new discoveries like the Dead Sea Scrolls or the Nag Hammadi Library. Of the historical Jesus we have only pieces, and for the most part, pieces of our own choosing. If we want to work theologically with the Jesus of history, this will have to do.

For many theologians, this would not do. For this reason, the New Quest lasted about ten years, but then faded and passed from the scene. Its practitioners were interested in theology, but they could not ultimately sustain the project with such a fragmentary base of operations. New Testament theology went back to the texts of the New Testament and began exploring the theology of the evangelists, Matthew, Mark, Luke and John, quite apart from the preaching of Jesus himself. Form Criticism gave way to Redaction Criticism and eventually to full-fledged literary criticism, leaving the 
problem of the origins of the gospel tradition behind. Historical Theology gave way to Narrative Theology, in which authoritative texts could provide a solid normative foundation for a linguistically-based theology of story. As for Käsemann, who issued the call for a new quest in the first place, he steered his career toward Paul, where extant letters give us access to the voice of the apostle himself. The quest for fragments of Jesus' life and preaching was too difficult and yielded results that were too meager and unsatisfying.

\subsection{The Re-Newed Quest}

The end of the New Quest created a problem. Professional theologians had a bit of knowledge they did not know what to do with. They knew that the gospels are not history, and that to recover history from them would be a task too troublesome to be useful for churches. And yet, just to explain this problem to a lay audience would itself be difficult and troubling. Theologians, and the pastors they trained, shuddered to think of how one might effectively break the news to an ordinary congregation that the gospel stories they had come to treasure were not history, but fiction. And facing this question in the 1960s and 1970s posed its own risks and difficulties. This was a period in which the historic Protestant denominations began losing members in droves. The cultural crises of that time had called into question modern institutional life in general, and the church, as an institution, suffered through this crisis of confidence along with other stalwarts of public life. Within the church, a new conservatism began to assert its grip on those who were left, hoping to stem the tide with a brave show of confidence in the past. This was not the time for theologians to come clean about the nature of the biblical texts. Fortunately, there was a way out. Narrative Theology provided an easily misunderstood professional discourse, in which one could speak of the biblical narratives with the tacit understanding that they were stories, not history, but without ever explicitly addressing the troubling question of historicity. It became fashionable to dismiss the historical question as unimportant or beside the point. 13 The result was an ever widening gap between lay Christians and professional theologians. Most lay people continued to assume that the church still considered the gospels to be historical, a comfort to conservative Christians, but a scandal to more progressive, criticallyminded persons, who either left the church in dismay, or simply held their piece in discomfort with one more institution that could not deal honestly with difficult questions.

This was the situation within which Robert W Funk declared the Quest on again with the founding of the Jesus Seminar in 1985. Funk had come to the end of a long and productive professional life in a variety of institutions - colleges, seminaries, universities - educating people into the ways of critical biblical scholarship, only to 
realize that his and the collective efforts of an army of biblical scholars working with the same critical presuppositions, were not making any difference at all. The only public voice addressing the issue of the Bible, or of religious faith in general, was the conservative voice of the Christian right wing, represented by popular preachers and television evangelists. Mainline denominational leaders knew they could not agree with these new evangelicals, but were not sure enough of their own position to really make any clear response to the growing wave of conservatism. Scholars had abandoned the field altogether, preferring the classroom and the library to public debate.

Funk stepped into the breach by assembling a group of about one hundred biblical scholars interested in pursuing the question of the historical Jesus. They came from a variety of backgrounds, from various denominations, both Roman Catholic and Protestant, and from teaching posts in seminaries, colleges and universities, both private and public. Funk's idea was to take on a central question, like the historical Jesus, in a self-consciously open forum as a way of educating the broader public into the ways of biblical scholarship. He invited the press. He created a process - the much ballyhooed voting on sayings of Jesus using different colored beads - that was easy to understand, and easily published. ${ }^{14}$ It worked. Soon the subject of the historical Jesus was once again on everyone's agenda. Those who did not have anything to say about Jesus himself, had plenty to say about keeping Jesus and the Jesus Seminar off the agenda and out of the news. Churches were caught off guard, wary of airing the critical basis of most mainline theology in public, and yet unable to repudiate what was being taught as a matter of course in most seminaries. Theologians committed to putting history aside in favor of a more narrative approach dismissed the new discussion and its promoters as unimportant and insignificant. But with Jesus once again on the cover of Time magazine, the protest rang hollow. The historical Jesus was turning out to be important after all.

The Jesus Seminar was not the only new scholarly effort to address the question of the historical Jesus. For example, in the same year that the Jesus Seminar began its deliberations, E P Sanders (1985) published his study, Jesus and Judaism, to critical acclaim. ${ }^{15}$ But like the Jesus Seminar, Sanders and others consciously avoided any attempt to make work relevant for theology. The quest for Jesus was on, but not the search for God. In the case of the Jesus Seminar, the participants were simply too diverse in their religious backgrounds and commitments to be able to offer anything like a coherent theological interpretation of their work. Others working within the confines of professional biblical scholarship had long since learned that revealing any theological agenda in connection with their historical work would only compromise their credibility within the academy. As the Quest for Jesus continued, it appeared as though it would go on without the theological interest that had always characterized it. 
But the theological stales associated with the figure of Jesus in western culture do not go away just because historically-oriented scholars choose not to address them. Whenever Jesus is the subject, someone in the discussion is thinking also about God. Culture has made Jesus more than simply an interesting historical figure; he is at the same time a religious symbol. As the discussion of the Re-Newed Quest broadened, its theological aspects began to emerge. Church groups began to study the results of the Jesus Seminar. The Five Gospels (Funk \& Hoover 1993) became the centerpiece of seminars on spirituality. Marcus Borg's (1994) autobiographical pilgrimage. Meeting Jesus again for the first time, became a religious best-seller. 16 A colloquium was convened to discuss the theological implications of John Dominic Crossan's work (see Carlson \& Ludwig 1994). And a vociferous back-lash began among conservatives, which by its very force demonstrated that Jesus was by no means a matter of simple historical interest. 17 Even the a-theological Jesus Seminar itself, has now decided to bribach the question of what the quest for Jesus might mean. Theology is once again on the table. The question is, how can we carry on a theological discussion about Jesus that is historically responsible, that makes sense in a pluralistic world, and yet still has the character of a theological discussion?

\section{A JESUS THEOLOGY?}

\subsection{False choices}

Throughout its history the problem of the historical Jesus has been received as a question of choices: either the historical Jesus or the church's Christ of faith. The initial discovery that these might not be the same thing, that the church's portrait of Jesus the Christ might not be an historical portrait of Jesus of Nazareth, produced among Christians a kind of disappointment and a resulting suspicion that has never really gone away. In the nineteenth century, this attitude of suspicion led to a fascination with the historical Jesus at the expense of the Christ of Christian faith. Back to Jesus! Forget Paul, and the rest of the church's theologians who have obscured, then forgotten, the clear voice of Jesus and his remarkable vision. This was the clarion call of nineteenth century Liberal Theology. One still hears this today as a kind of first response to the work of the Jesus Seminar and others who are reintroducing the problem of the historical Jesus to a broad public audience.

But the new world of Liberal Theology never came. In fact, as Christendom entered a new century its vision seemed more distant than ever. A new voice, advocating a different choice, was soon to be heard in the new advocates of orthodoxy. These neo-Orthodox theologians, such as Karl Barth, argued that what the world needed was 
not a teacher, but a savior with the power to lift humanity from out of its utter sinfulness. A new call went out: forget Jesus, fast forward to Paul, the first person really to see the significance of Jesus, the Christ, our savior. One still hears this view expressed today among the critics of the Re-Newed Quest. The Jesus who emerges from this newest phase i.l the quest for the historical Jesus, they argue, is little more than ordinary, a mere human being incapable of inspiring the faith we know to have been the result of his life, death, and resurrection.

But to pose the problem of the historical Jesus as a choice is a mistake. After all, earliest Christians did not see the necessity of making a choice between the historical Jesus and the Christ of faith. The historical Jesus was their Christ of faith. As the New Quest advocates of the 1950s and 60s rightly pointed out, the earliest Christian preaching about Jesus did not replace him with something new and different. The new things they said about Jesus, they still said about Jesus (see, for example Käsemann 1964:30-34; Robinson 1959:78-79). Nonetheless, the earliest Christians did say things about Jesus that Jesus himself did not say. Christian preaching was indeed something different, not a repetition of what Jesus said. So how are we to understand the relationship between the preaching of Jesus and the preaching of the earliest Christians? What is the structure of earliest Christian faith and what are the real choices it offers us?

\subsection{The structure of earliest Christian faith}

Solving this problem takes some imagination - not much, but some. Let us imagine an encounter with the historical Jesus. Like most itinerant preachers/teachers, Jesus would have been found on occasion in the market place of an ancient town. Let us imagine such a situation. As he begins to teach, a small crowd gathers. Willi Marxsen ([1968] 1992:1-15) liked to remind us that among those first hearers of Jesus there would have been various reactions. 18 We cannot imagine that everyone who heard Jesus was so taken with his words that immediately they fell down and worshipped him. His fate just does not bear this out. He was, after all, tried in a court of law, convicted, and sentenced to death, and all this, presumably, for something he said or did. Nor can we imagine that at the end of every speech, Jesus performed some miraculous deed to prove the veracity of what he had just said. Again, remember his fate. As Crossan (1994:199-200) has more recently remarked, any plausible historical reconstruction of Jesus must take into consideration that when people heard him and saw what he was doing, some said 'Let's execute him,' while others said 'Let's worship him'. And there were other responses, from offense, to excitement, to indifference. But whatever the response was, it was always a response to Jesus. This is true of both the negative and the positive responses, the 'Let's execute him' and the 'Let's worship him,' and even the 'Who cares?' 
This is the structure of earliest Christian faith. The confessions of faith uftered by Jesus' followers did not replace what Jesus had said and done with new claims that were unconnected to their experience of him. Their confessions of faith in Jesus were a response to what he had said and done. Unlike those who were moved to anger by Jesus, or those for whom his words and deeds were a matter of complete indifference, those earliest Christians claimed that in his words and deeds they had come to know who God really is, what God is really like. Why? Simply because they had experienced him that way. They heard Jesus' words and risked calling them the Word of God because they chose to believe in the kind of God they saw in him. Their responses of faith did not replace what Jesus had said and done with something new. Rather, they elevated what they had experienced in Jesus to a new kind of status: a claim about who God is, a theological claim.

If this is true, then one can see that the difference between the historical Jesus and the Christ of faith does not force us into a choice between the two. Rather, in order to have Christian faith one needs both. On the one hand, the historical Jesus by himself does not necessarily yield Christian faith. He is only a teacher, to whom many different responses were/are possible. A teaching, a life, is not yet a religion. It must move you, utterly so, beyond mere interest or fascination, to the point of risking the claim that in this person I have seen God.

On the other hand, early Christian declarations of faith in Christ are, by themselves, also inadequate. To say 'Jesus is the Son of God' means nothing, unless, of course, one knows something about this Jesus. The point, after all, is not simply to assert that there is a Son of God. Ancient people would have taken this for granted. Divine off-spring walking among us on the face of the earth belonged to the common religious mentality of the ancient world. Asclepius, Heracles, Augustus Caesar - they were all sons of a god. So why would one say that Jesus was a son of a god, or even the Son of God? It could only be because one had chosen not to believe in a God of perfect health (Asclepius), of infinite strength (Heracles), or of wealth and brutal power (Augustus). One had chosen to believe in a God whose character is seen in Jesus. But who is that God? What is the substance of the theological claim being made in such a confession of faith? This can only be supplied by Jesus himself, what he said and what he did that so moved people to make the claim that in him they had come to know who God is. As Crossan (1994:20) has so succinctly put it: "Christian belief is always (1) an act of faith (2) in the historical Jesus (3) as the manifestation of God.'

\subsection{What's in a title?}

We can illustrate this point by looking at the titles early Christians commonly ascribed to Jesus, titles such as 'Christ,' 'Lord,' or 'Savior.' These titles have become familiar 
to us as Christian titles. But they, of course, did not start out that way. NonChristians used them long before they were applied to Jesus. So what makes Christianity any different from other forms of Judaism, which proclaimed the arrival of the messiah, or from the imperial cult of the caesars, which hailed Augustus as its lord and savior? The distinctiveness of Christianity lay not in these titles, but in the fact that early Christians applied them to Jesus, who said and did certain things. To get at the substance of the claims Christians were making when they applied these titles to Jesus, one must first take seriously what Jesus said and did that made this seem like the appropriate response to Jesus. ${ }^{19}$ For example, Jesus once said that the Empire of God is like this:

A person once gave a great banquet, and invited many guests. And when it came time for the banquet, he sent his servant around to the invited guests to say 'Come, for everything is now ready.' But they all, one after another, began to make excuses. The first guest said to him, 'I've bought a field and must go out to look it over. Please pass along my regrets.' And another said, 'I've bought five yoke of oxen and must go examine them. Please pass along my regrets.' And another said, 'I have just gotten married and so cannot come.' So the servant went and reported this to his master. Then the householder got angry and said to his servant, "Go out right away into the streets and alleys of the city and bring in the poor, the blind and the lame.' And the servant said, 'What you have commanded has been done, but there is still more room.' So the master said to the servant, "Go out to the highways and hedges and compel people to come in, so that my house might be filled. For I tell you, none of those who were invited shall ever taste my banquet. 20

Now we have something to work with. Let's go back to those titles: what did early Christians mean by calling Jesus names like 'Christ,' 'Lord,' and 'Savior'? The first of these, 'Christ,' is just the Greek word for 'messiah.' Both mean 'the anointed one.' In Jewish culture, anointing was part of the ceremony for installing the king. The anointed one is the king. So Messiah or Christ is a common title having nothing to do originally with Christianity. In Jesus' time the hope for a new messiah was bound up with the hope for a new kingdom in which Israel might be freed from Roman rule and turn once again to live in faithfulness to God. So what does it mean to call Jesus 'Christ' or 'Messiah'? It is to proclaim that with Jesus the reign of God was here, that 
it was and is just as he described it. Is it possible to believe that this is true? Can one believe that the reign of God is like a banquet in which all find a place? Can one believe that God will welcome into it anyone who dares to come in? That is what it means to call Jesus the Christ. It is to accept his vision of the banquet and the God who comes with it.

The title 'Lord' is also common and early in Christianity. What does it mean to say 'Jesus is Lord?' Is this a different order of claim? A lord - in Greek kurios - is one who has servants at his disposal. Like 'Messiah' or 'Christ', 'Lord' is a common title not having to do originally with Christianity. In fact, it is not always a religious term at all. To say, 'so and so is my lord,' is to place oneself at the disposal of someone, to do their work, to respond to their commands. So to confess Jesus as one's Lord is simply to ask 'What am I to do in the service of Jesus?' What does Jesus command one to do? Go out into the streets, and gather in anyone you find. Fill up the banquet hall! Is it possible to do this? Is it possible to open up the table so that all may come? Is it possible to enact the vision of the reign of Ged Jesus offers? This is what would mean to claim Jesus as one's Lord.

And what about 'Savior'? What does it mean to say 'Jesus is my Savior'? The ancient world was full of saviors: Isis, Ashtarte, Sarapis, Asclepius, Zeus, Augustus Caesar. Saviors were so plentiful in antiquity because antiquity was so rough. Ancient life was 'nasty, brutish and short,' to appropriate the aphorism of Hobbes. Many people asked 'Is there anyone who cares about me? Is life more than random violence with brief interludes of tolerable peace? Is there a God who cares what happens to me personally, who loves me?' These are the questions behind the quest for a savior. A savior is one who cares about me, who loves me, who will protect me. Where is that care to be found? Where can one find that kind of love and security? In the military power of the Emperor? In the healing touch of Asclepius? In the mysterious inner sanctum of the Isis temple? When early Christians claimed Jesus as their Savior, they were claiming that the love of God was to be found around the open tables of the Jesus movement. It was there that they experienced care. It was there that they experienced love. It was there that they experienced the safety and security that comes only from knowing experientially that there is a God who cares about me personally. Jesus created an experience of the unmitigated love of God for those in his world who had experienced it least: the poor, the blind, the lame, the homeless. They in turn confessed him as 'Savior.'

So the historical Jesus is important. And so are the confessions of the early church. That Jesus' reign is the reign of God, that he makes demands on one's life, that in him ont can find refuge - these are the things that come from the confessional 
language of the early church. But what is that reign like? What does Jesus demand of me? What does it feel like to be embraced by God? These questions can only be answered if one pays close attention to the person whom early Christians confessed as Christ, Lord, and Savior: Jesus of Nazareth, the historical Jesus.

\subsection{A resurrection or The resurrection?}

This point may be further illustrated by exploring one of the most important and basic Christian confessional claims about Jesus: that God raised him from the dead. Many Christians assume that 'the resurrection' is that one, great miraculous event that gave Christian faith a jump-start and proves once and for all that Christians have a unique claim on the truth about God. But to someone living in the ancient world, such an attitude would not have made much sense. The problem is this: when one speaks today of 'the resurrection,' no one ever asks what he or she is talking about. We all know whose resurrection the resurrection is. Since the resurrection of famous people is no longer part of our world view (excepting, perhaps, the world view of the tabloids), we have reserved a special and unique place for Jesus' resurrection. It appears to us like an utterly unique event. By itself it appears quite adequate to inspire faith in Jesus as the Son of God, regardless of what he said or did.

But to ancient ears, the resurrection of Jesus would not have sounded quite the same. One could never say 'the resurrection' and expect that everyone would know what you were referring to. The first question an ancient would want to ask is: Whose resurrection? That there was a resurrection is not the question. Everyone knew about famous resurrections. Resurrection was a confessional element of most ancient religions. So to say that God raised someone from the dead ... well, by itself, it really does not say much. It depends on who: Who was raised from the dead? What did he say? What did she do? What did he stand for that God would raise him from the dead?

Most people in Jesus' day believed that the Emperor Augustus had been raised from the dead. Now, there was a religion. All over the Mediterranean world one can find its legacy still today in grand temples and arches, dedicated to the gods 'Rome and Augustus.' Rome was very clear about what it believed in. It believed in power. No one embodied that more than Augustus. He conquered lands far and wide, from which great treasures were extracted. He subjugated cultures, gave them a new language, new institutions. He quashed rebellions. His life was one great manifestation of power. The Imperial Cult was about power. And the great thing about a religion of power is that it provides its own authentication: victory reveals the favor of the gods. Resur- 
rection became the ultimate symbol of that religion: the final victory. The ultimate bestowal of power was to rise beyond the limits of this world to join the great pantheon of the gods in heaven.

Now, if one looked just at the resurrection in Christianity, one might get the impression that Christian faith was about this too, about power. And many have made the mistaken assumption that the resurrection shows that the Christian god is the most powerful god, and that this power is to be used to subjugate inferior, less powerful cultures. If one looks critically and honestly at the history of bringing Christian faith to places like Africa, Asia, the Americas, Hawaii, one has to admit that Christians have indeed been confused about this at certain times in our history.

But earliest Christians did not just proclaim a resurrection, as though the power of such a demonstration was the point. This confessional statement was attached to a history, the history of a person, Jesus of Nazareth. He was not powerful, but the victim of power. He did not believe in the Empire, but proclaimed another Empire, the Empire of God. He said things like:

Blessed are you beggars, for the Empire of God belongs to you;

Blessed are you hungry, for you will be satisfied;

Blessed are you who cry and are depressed, for you will laugh;

Blessed are you when people despise you, and exclude you, make fuil of you, and curse you, for prophets have always been treated like this. ${ }^{21}$

He said to religious leaders: 'Prostitutes and sinners go into the Empire of God before you 22.' God raised him? He said what? Who is this God, whose empire belongs to beggars? What kind of religion focuses on these marginal people and makes them the center of God's concern? These are the questions posed by the claim that God raised Jesus from the dead.

\subsection{An existential Christology}

So, if one proclaims that God raised Jesus from the dead, that Jesus is the Son of God, then it makes a difference what he said and did, what people experienced of him that moved them to say such things. Jesus' words and deeds in this way give definition and character to Christian theology - they make it Christian! And for this same reason, for the Christian, the quest for the historical Jesus will also always be about the search for God. However, this way of coming to see God in Jesus will for many people involve coming to see Jesus and his significance for Christians in a way that is profoundly different from what many have assumed to be normative, orthodox thinking about such things. Let me explain. 
When most people today say something like 'Jesus is God's Son,' they mean to say that there was something about Jesus that was essentially different from all other human beings. It is not just that he behaved in an unusual way. He was different in his essence, in his being. This idea may be seen in the words of a placard hoisted aloft several years ago by a protester outside an Atianta theater during the showing of the controversial Scorsese film, The Last Temptation of Christ. It read, 'My Savior is not human!' These are the words of a zealot, but they express with a clarity afforded only in hyperbole what many Christians think about Jesus. They think that in his essence, Jesus was not really human after all. He was divine.

The problem with this essentialist approach to Christology, an approach encouraged throughout the last generation of positivist theologians, such as Karl Barth, is that for many modern folk it has become incredible in a way that was not so for the ancient folk who created the texts of the New Testament.

For ancients, the idea that a human being might be essentially divine made sense. In a world view in which Gods sometimes mated with human beings, the offspring of such a conjugation, a divine human being, was a distinct possibility. Today, of course, no one believes this. But many still believe that Jesus was essentially divine, accepting this as an article of faith, even though the mythic framework within which such belief might have made sense has long passed from our cultural consciousness. It remains as the text of a placard, a rallying cry. But it is a claim without much meaningful content in the modern world. It is perhaps the centerpiece of a modern Christianity that has been drained of most of its content and meaning.

What I have been describing in the final pages of this article is an alternative to this essentialist approach to Christology. I will call this approach an 'existential Christology. ${ }^{23}$ It is based on the idea that the early followers of Jesus did not make claims about him because they had somehow sensed in him a different essence, a palpable divinity. When they said of him, 'Behold, the Son of God,' it was not because they had seen a halo circling his head. It was because they had heard him say and seen him do certain things. They experienced him acting in their lives. And what they experienced in the company of this person, Jesus, moved them deeply. They heard in his words profound truth about the world, about human nature, and about God. They experienced in his actions what authentic human being can and should be like. In his life they experienced a depth of meaning that tapped into what they knew to be true, ultimately true. Such truth is called, in normal religious parlance, God. God is that ultimate reality running through and beyond all things, in which all things have their grounding, in which life, if it is to have any meaning at all, must also be grounded. In their experience of Jesus, the followers of Jesus had experienced God. In his followership they had found the true meaning of their lives. And so they said of him, 'Behold, the Son of God.' 
An existential approach to Christology takes this basic experience as the foundation of Christian faith. Christian faith began with a decision to see in Jesus' words and deeds the deepest of all truths, the truth that is God. This is what Christian faith was, and must become if it is ever again to have any meaning in the modern world. But this means that historical Jesus scholarship cannot be regarded as a matter of indifference to Christian theology, an interesting sidelight, or side show. New Testament scholarship must again and again take up the question of the words and deeds of Jesus, to the extent that responsible historical scholarship makes this possible, in such a way that reveals what they meant to the folk who decided that in Jesus they had come to know who God is. What did Jesus do? What did Jesus say? And why did these things matter to folk? Can they matter again in our own time?

* This essay was originally presented as a paper to the Spring 1996 meeting of the Jesus Seminar in Santa Rosa, California, on February 28, 1996. A version of it appears as the chapter 1 of the author's book, The historical Jesus and the search for God (Valley Forge, PA: Trinity Press International, 1998).

\section{End Notes}

1 The seminal description of this basic cultural difference and the problems it poses for the modern interpreter of scripture was (and remains) Rudolf Bultmann's classic essay, 'New Testament and mythology.' Published originally in German in 1941 (part II of Offenbarung und Heilsgeschehen; Beiträge zur Evangelische Theologie 7 (Munich: Lempp, 1941]), this essay has been translated and reprinted in a number of different forms. An excellent translation is to be found in Rudolf Bultmann 1984:1-44.

2 As quoted from Luther's correspondence with Cajetan by Roland Bainton (1950:96). Luther and Calvin were not hostile to scientific avancement and the use of reason in the service of Christian faith (see Gerrish 1982:163-178).

3 Reimarus' fragment 'On the intentions of Jesus and his disciples' is available in an English translation by Ralph S Fraser, edited by Charles H Talbert, Reimarus: Fragments (Philadelphia: Fortress, 1970). Talbert's excellent 'Introduction' is the source of most of the information about Reimarus presented here.

4 . These creative ideas come from the work of Karl Friedrich Bahrdt, who wrote a weekly newsletter on the Bible in the 1780s and 90s. His views are reported by Albert Schweitzer ([1906] 1910) in his classic treatment of the first quest for the historical Jesus, The quest of the historical Jesus, published in German originally in 1906 with the title Von Reimarus zu Wrede (Tübingen: Mohr). Schweitzer's masterful treatment of the quest during this period is widely regarded as the standard. For Bahrdt's views on miracles see p 41.

5 See previous note. 
6 The original two-volume work was called Das Leben Jesu, kritisch bearbeitet (Tübingen: Osiander, 1835-36). The book appeared in three subsequent editions. In the Third Edition (185839), Strauss softened his position, moving closer to the great spokesperson for Liberal Christianity, Friedrich Schleiermacher. But in 1840, a new edition appeared, in which these changes were withdrawn. An English translation by George Eliot first appeared in 1846. This was recently reprinted with an introduction and notes by Peter C Hodgson, as The life of Jesus critically examined (Philadelphia: Fortress, 1972).

7 As noted by Leander Keck (1977:xvii) in the 'Introduction' to his translation of Strauss' The Christ of faith and the Jesus of history: A critique of Schleiermacher's 'Life of Jesus'. Keck notes that the ephithet so effectively took that it apparently generated that Strauss was red-haired, as was Judas in traditional portrayals of the time.

8 The question of Jesus' commitment to apocalypticism has re-emerged as a question in the most current phase of the discussion. The field, once united around the Weiss/Schweitzer hypothesis, is now once again divided. For an account of how this shift has come about, and its possible consequences, see Patterson (1995:29-48).

9 In view of this it may seem somewhat incongruous that Bultmann in fact wrote a very wellknown book on Jesus, Jesus and the Word (New York: Charles Scribner's Sonts, 1934; German original published in 1926). This is especially so since it will be recalled that Bultmann first published his History of the synoptic tradition in 1921, a book that is frequently credited with creating a new standard of skepticism about the historicity of the gospel tradition. But in fact it is not so incongruous. In The history of the synoptic tradition Bultmann is far more positive about the historicity of the tradition than is frequently realized, especially when it comes to discrete sayings assigned to Jesus. It is such sayings that are the focus of his attention in Jesus and the word. The justification for this focus on Jesus' words, which would come to characterize the work of Bultmann's students in the later New Quest (see below), can be found already in Kähler ([1892] 1964: 82), who generally despaired of historical work, but allowed that the words of Jesus provide a kind of historical reference point to check our fantasies about the kind of person Jesus was.

10 Käsemann published the essay in German in 1954 as: 'Das Problem des historischen Jesus,' ZTK 51, 125-153; it appeared in English as 'The problem of the historical Jesus,' Ernst Käsemann (1964:15-47).

11 This criterion, commonly referred to as 'dissimilarity,' naturally posed problems for the New Questers in exploring the lines of continuity between the preaching of Jesus and that of the early church. For example, the continuity Käsemann saw between Jesus' preaching in the antitheses of the Sermon on the Mount and the early church's claim that Jesus was the messiah rests on the assumption that the antitheses of the Sermon on the Mount do in fact go back to Jesus. But given Matthew's general interest in presenting Jesus as an interpreter of the law, it is quite plausible to suppose that these antitheses do not go back to Jesus, but come from Matthew himself. In this case, Käsemann overlooks his own criterion on the way to achieving the desired result. 
12 Scholars do not always spell out clearly the criteria they actually use in determining what is historical and what is not. One recent attempt at clarity is Robert Funk's listing of all the 'Rules of Evidence' used at one time or another by the Jesus Seminar in its deliberations (Funk \& Hoover 1993:16-34). This part of the Jesus Seminar's work has been criticized because it seems to preprogram the results. In fact, however, this was not so. Funk's Rules of Evidence were compiled deductively, by looking back over the work of the Seminar and identifying the trends that developed over the course of several years. Another approach is offered by John Dominic Crossan in The Historical Jesus: The Life of a Mediterranean Jewish Peasant (San Francisco: HarperCollins, 1991). Rather than using strict criteria, Crossan uses a combination of historical and cross-cultural anthropological information to complement a critical reading of the pre-gospel tradition.

13 Much of this school of thought grew up around a cluster of theologians at the Yale Divinity School, including George Lindbeck (1984), Brevard Childs (1979), and Hans Frei (1974). All are heavily indebted to Karl Barth's view of scripture, as interpreted by Frei.

14 The Jesus Seminar published its results in a popularly accessible form in The Five Gospels (see note 12, above) (Funk, Scott \& Butts 1988) and the Gospel of Mark (Funk \& Smith 1991). In addition it published a small volume on parables Volumes on Matthew, Luke and Thomas are also planned. In addition, a second popularly accessible volume on the deeds of Jesus is planned for 1998.

15 E. P. Sanders, Jesus and Judaism (Philadelphia: Fortress, 1985). Since 1985 a raft of new books on Jesus has appeared from every conceivable perspective, including those by Richard Horsley (1987); F Gerald Downing (1987); Marcus Borg (1987); John Dominic Crossan (1991, 1994); John P Meier (1991, 1994); Bruce Chilton (1996); Robert W Funk (1996); N T Wright (1996), to name just a handful of the many. Noteworthy also is a collective effort to assess the state of the discussion: Bruce Chilton \& Craig A Evans (1994); and a new annotated bibliography: Craig A Evans (1989).

16 Marcus Borg, perhaps more than any other person involved in the current discussion, has been concerned to relate Jesus to contemporary religious faith. See, for example, his essays, 'The Jesus Seminar and the Church,' and 'Does the Historical Jesus Matter?' pp. 160-181 and 182-200, respectively in his collected essays, Jesus in Contemporary Scholarship (Valley Forge, PA: Trinity Press International, 1994).

17. See, e g, Hays (1994:43-48); Wilkins \& Moreland (1995); or Johnson (1996).

18 See expocially Marxsen's (1968:214-225) essay, 'Jesus hat viele Namen,' in his Der Exeget als Theologe (Gütersloh: Gütersloher Verlagshaus Mohn, 1968), translated as 'Jesus has many names,' in the collection of Marxsen's (1992:1-15) essays, Jesus and the church: The beginnings of Christianity. This volume contains several essays of relevance to the approach taken here to the question of the relationship of the historical Jesus to the beginnings of Christian theology. 
19 As Marxsen (1992:7) says so clearly, 'We noed to pay attention precisely to the direction in which the statement "Jesus is the Messiah" came into being. It was not a matter of transferring all current messianic conceptions to Jesus, but rather of rediscovering (in the Messiah-cnncept) experiences one had had with Jesus. The name that Jesus receives has to be filled with content from the experiences one had had with Jesus - not from current messianic conveptions.

20 This is Luke's version of the parable of the Great Feast ( $\mathrm{Lk}$ 14:16b-24), versions of which are also found in Matthew (Mt 22:2-13) and the Gospel of Thomas (Thom 64). Luke's version, which the Jesus Seminar designated 'pink' (meaning that Jesus probably said something like this), is close enough to an original parable of Jesus for our purposes here.

21 These are the beatitudes more or less as they appear in Luke's Sermon on the Plain (Lk 6:20b23). They are also found in Matthew's Sermon on the Mount (Mt 5:3-4, 6, 10-12) and the Gospel of Thomas (Tom 54, 69:2, 68:1). The Jesus Seminar designated the first three beatitudes in their Lukan form 'Red' (meaning that Jesus said this or something very close to this). The fourth I have modified to remove the early Christian apologetical motifs that caused the Jesus Seminar to designate it 'Gray' (meaning that Jesus probably did not say this, but it still may contain ideas consistent with Jesus' views). In this form I would designate it 'Pink.'

22 Matt 21:31b. A small majority of the Fellows in the Jesus Seminar designated this saying 'Red' or 'Pink,' but the stronger feeling of the minority against attributing it to Jesus led ultimately to a weighted average in the 'Gray' designation. I would assign it a 'Pink' designation.

23 This approach is essentially that of Willi Marxsen (1992) and the American theologian, Schubert Ogden (1982), whose work has been influenced by Marxsen.

\section{Works Consulted}

Bainton, $\mathrm{R}$ 1950. Here I stand: A life of Martin Luther. Nashville, TN: Abingdon.

Borg, M J 1987. Jesus: A new vision. San Francisco, CA: Harper \& Row.

1994a. Meeting Jesus again for the first time. San Francisco, CA: HarperCollins.

1994b. The Jesus Seminar and the Church, in Jesus in contemporary scholarship, 160-181. Valley Forge, PA: Trinity Press International.

1994c. Does the historical Jesus matter?, in Jesus in contemporary scholarship, 182-200. Valley Forge, PA: Trinity Press International.

Bultmann, R [1926] 1934. Jesus and the Word. New York, NY: Charles Scribner's Sons.

Bultmann, R [1941] 1984. New Testament and mythology, in New Testament and mythology and other basic writings, selected, edited and translated by S M Ogden, 1-44. Philadelphia, PA: Fortress. 
Carlson, $\mathrm{J} \&$ Ludwig, $\mathrm{R}$ (eds), Jesus and faith: A conversation on the work of John Dominic Crossan. Maryknoll, NY: Orbis Books.

Childs, B S 1979. Introduction to the Old Testament as Scripture. Philadelphia, PA: Fortress.

Chilton, B 1996. Pure kingdom: Jesus' vision of God. Grand Rapids, MI: Eerdmans.

Crossan, J D 1991. The historical Jesus: The life of a Mediterranean Jewish peasant.

San Francisco, CA: HarperCollins.

1994. Jesus: A revolutionary biography. San Francisco, CA: HaperCollins.

Downing, F G 1987. Jesus and the threat of freedom. London: SCM.

Evans, C A (ed) 1989. Life of Jesus research: An annotated bibliography. Leiden: Brill. (NTTS.)

Evans, C A \& Chilton, B (eds) 1994. Studying the historical Jesus: Evaluations of the state of current research. Leiden: Brill. (NTTS.)

Frei, H 1974. The eclipse of biblical narrative. New Haven, CT: Yale University Press.

Funk, R W 1996. Honest to Jesus. San Francisco, CA: HaperSanFrancisco.

Funk, R W, Scott, B B \& Butts, J R (eds), 1988. The parables of Jesus: Red letter edition. Sonoma, CA: Polebridge.

Funk, R W \& Smith, M (eds) 1991. The Gospel of Mark: Red letter edition. Sonoma, CA: Polebridge.

Funk, R W \& Hoover, R W (eds) 1993, The Five Gospels. New York, NY: Macmillan.

Gerrish, B A 1982. The old Protestantism and the new. Chicago, Il: University of Chicago Press.

Hays, R B 1994. The corrected Jesus. First Things 43, 43-48.

Horsley, R A 1987. Jesus and the spiral of violence. San Francisco, CA: Harper \& Row.

Johnson, L T 1996. The real Jesus: The misguided quest for the historical Jesus and the truth of the traditional gospels. San Francisco, CA: HarperSanFrancisco.

Kähler, M [1892] 1964. The so-called historical Jesus and the historical Biblical Christ; translated and edited, with an introduction by C E Braaten. Philadelphia, PA: Fortress, 1964.

Käsemann, E [1954] 1964. The problem of the historical Jesus, in Essays on New Testamen themes, tr by W. J. Montague, 15-47. Naperville: Allenson/London: SCM. (Studies in Biblical Theology.)

Käsemann, E [1965] 1969. Blind alleys in the 'Jesus of History' controversy, in New Testament questions of today. Philadelphia, PA: Fortress. 
Keck, L 1977. Introduction, Strauss, D, The Christ of faith and the Jesus of history: A critique of Schleiermacher's 'Life of Jesus', xvii. Philadelphia, PA: Fortress.

Lindbeck, G 1984. The nature of doctrine. Philadelphia, PA: Westminster.

Patterson, S J 1995. The end of apocalypse: Rethinking the eschatological Jesus. Theology Today 52/1, 29-48.

Marxsen, W [1968] 1992. Jesus has many names, in Jesus and the church: The beginnings of Christianity, 1-15, selected, translated and introduced by $\mathrm{P} E$ Devenish. Philadelphia, PA: Trinity Press International.

Meier, J P 1991. A marginal Jew: Rethinking the historical Jesus, Vol One: The roots of the problem and the person. New York, NY: Doubleday.

1994. A marginal Jew: Rethinking the historical Jesus, Vol Two: Mentor, message, and miracles. New York, NY: Doubleday.

Ogden, S M 1982. The point of Christology. San Francisco, CA: Harper \& Row.

Reimarus, H S [1774-1778] 1970. On the intentions of Jesus and his disciples, in Reimarus: Fragments, tr by R S Fraser and ed by C H Talbert. Philadelphia, PA: Fortress.

Robinson, J M 1959. A new quest of the historical Jesus. Naperville: Allenson/London: SCM. (Studies in Biblical Theology.)

Schweitzer, A [1906] 1910. The quest of the historical Jesus. London: Adam and Charles Black.

Sanders, E P 1985. Jesus and Judaism. Philadelphia. PA: Fortress.

Strauss, D [1835-1836] 1972. The life of Jesus critically examined, translated by G Elliot, reprinted with an introduction and notes by P C Hodgson. Philadelphia, PA: Fortress.

Weiss, J [1892] 1971. Jesus: Preaching of the Kingdom of God. Philadelphia, PA: Fortress.

Wilkins, M J \& Moreland, J P (eds) 1995. Jesus under fire: Modern scholarship reinvents the historical Jesus. Grand Rapids, MI: Zondervan.

Wright, N T 1996. Jesus and the victory of God. Minneapolis, MN: Fortress. 